\author{
MARLENA KILIAN* \\ Warszawa, Polska \\ ORCID ID: https://orcid.org/oooo-ooo2-7285-9784
}

\title{
MOTYWY SPOŁECZNEGO UCZESTNICTWA SENIORÓW W ŚWIETLE WYBRANYCH TEORII MOTYWACJI
}

\begin{abstract}
Streszczenie: Celem artykułu jest określenie motywacji starszych osób do efektywnej pracy i podejmowania aktywności zawodowej po uzyskaniu uprawnień emerytalnych, w świetle analizy klasycznych teorii motywacji i badań empirycznych. Opracowanie ma charakter przeglądowy. Z przeprowadzonej analizy wynika, że w wieku senioralnym dla działalności zawodowej podstawowe znaczenie ma potrzeba wartościowego spędzania czasu, kontakt z innymi ludźmi, uczenie się i aktywność umysłowa, radość z wykonywania cenionej pracy, satysfakcja z wykorzystywania własnych umiejętności i kreatywności, poczucie zawodowych osiągnięć. W zaawansowanym wieku źródłem satysfakcji z pracy w większej mierze stają się czynniki wewnętrzne aniżeli zewnętrzne nagrody. Dla wzbudzenia wśród pracowników w wieku późnej dorosłości motywacji do pracy należy dać im możliwość wykonywania zadań w kontakcie z innymi ludźmi, w przyjemnej, pozbawionej stresu i presji atmosferze, prowadzących do rozwoju i samorealizacji.
\end{abstract}

Słowa kluczowe: motywacja; teorie motywacji; praca; aktywizacja; starość.

\section{Wprowadzenie}

Na tle Europy poziom uczestnictwa społecznego osób starszych jest w Polsce niewielki (Szatur-Jaworska 20o8), co przejawia się również ich obniżonym zaangażowaniem na rynku pracy - wskaźnik aktywności zawodowej osób w wieku 50+ należy do najniższych w Unii Europejskiej (Błędowski 2013). Znalezienie efektywnych

* Dr Marlena Kilian, Uniwersytet Kardynała Stefana Wyszyńskiego w Warszawie, Wydział Nauk Pedagogicznych; e-mail:m.kilian@uksw.edu.pl. 
strategii motywujących seniorów do wydłużenia okresu aktywności zawodowej lub powrotu na rynek pracy po przejściu na emeryturę, to jedno najpilniejszych wyzwań stojących przed starzejącym się społeczeństwem. Działania na polu praktyki wyprzedzać powinno dogłębne rozpoznanie motywów kierujących starszymi pracownikami w życiu zawodowym.

Celem niniejszego artykułu było określenie motywacji starszych osób do efektywnej pracy i podejmowania aktywności zawodowej po uzyskaniu uprawnień emerytalnych, w świetle analizy wybranych teorii motywacji i badań empirycznych. W myśl Ustawy o osobach starszych z 2015 r. za próg starości uznano wiek 60 lat, wobec czego wiek starszy, wiek zaawansowany czy senioralny to terminy odnoszące się do osób, które ukończyły 60 rok życia (starość w ujęciu kalendarzowym), choć niekoniecznie osiągnęły wiek emerytalny (starość w ujęciu prawnym).

\section{Uczestnictwo społeczne i etos pracy w życiu człowieka}

Wyrazem uczestnictwa społecznego jest podejmowana przez człowieka praca. Dowodzi ona jego sprawczości, pozwala przekształcać otaczającą go rzeczywistość, ale również jego samego. Umożliwia rozwój i samorealizację, a dzięki obserwacji efektów własnej pracy, które mogą być trwalsze od samego człowieka, który przemija, daje poczucie odciskania trwałego piętna w świecie. Poprzez pracę człowiek wyraża i urzeczywistnia samego siebie, jeszcze bardziej staje się człowiekiem, dlatego jest ona dla niego dobra (Jan Paweł II 1995). W tym znaczeniu jest wartością, chociaż na podstawowym poziomie może być tylko sposobem na zapewnianie materialnych warunków egzystencji.

Satysfakcjonująca praca nie jest podejmowana z przykrej konieczności, ale z potrzeby samorozwoju, samorealizacji, odkrywania sensu życia. Jest sposobem na uczestnictwo w życiu społecznym i tworzenie społecznego kapitału. Daje poczucie wspólnoty i społecznej łączności - wykonywana jest w powiązaniu z innymi osobami i służy nawiązywaniu i pogłębianiu z nimi relacji. Praca to podstawowa forma działalności ludzkiej, pozwalająca człowiekowi określić swoje miejsce w społeczeństwie (Wiatrowski 2005). Bezczynność, nawet opłacona świadczeniem socjalnym, nie jest satysfakcjonującym ekwiwalentem pracy, ponieważ działa na człowieka zubożająco. To nie synonim odpoczynku, który, zasłużenie, następuje po podjęciu wysiłku.

W starszym wieku zmiana roli społecznej - z pracownika na emeryta - często oznacza przejście od pełnej aktywności do zupełnej bezczynności, rodzącej poczucie wyizolowania ze społeczeństwa i nieprzydatności, deprywacji potrzeb wyższego, ale czasem również niższego rzędu (Pikuła 2017). Ograniczenie społecznego uczestnictwa zaburza zdolności funkcjonalne człowieka i nosi znamiona upośledzenia, rozwijającego się w zetknięciu z barierami społecznymi utrudniającymi codzienne funkcjonowanie. Model niepełnosprawności WHO (International Classification of Functioning, Disability and Health - ICF) (2001) podkreśla znaczenie czynników 
środowiskowych, które mogą utrudniać uczestnictwo jednostki w życiu społecznym bądź je ułatwiać. Niska aktywność społeczna seniorów nie musi mieć medycznego uzasadnienia. Możliwa jest sytuacja, kiedy niepełnosprawna osoba jest zdrowa, a przyczynę jej trudności w codziennym funkcjonowaniu i wypełnianiu obowiązków stanowią czynniki środowiskowe, np. przymusowa dezaktywizacja zawodowa i bariery w sferze społecznego zaangażowania emerytów.

Uczestnictwo społeczne seniorów łączy się z ideą aktywnego i pomyślnego starzenia się. Aktywne starzenie (UE) zakłada, że osoby będą partycypować w życiu społecznym, również na poziomie gospodarczym. W zakres aktywności społecznej, oprócz działalności zawodowej, wlicza się również działalność wolontarystyczną, opiekę nad wnukami i własnymi starszymi już rodzicami, aktywność polityczną, ale też rekreację. Powszechne jednak zjawisko mitologizacji emerytury jako czasu przeznaczonego głównie na odpoczynek, przesłania wartość prospołecznej aktywności, zwłaszcza tej, która wykracza poza więzy rodzinne. Z uwagi na negatywne dla jakości życia seniorów skutki trwałej bezczynności z jednej strony, oraz korzyści $\mathrm{z}$ podejmowanego wysiłku pracy z drugiej, motywowanie do aktywności, również zawodowej, staje się sprawą wielkiej wagi. Potrzebne jest takie zachęcanie do pracy, podejmowanej w trybie formalnego zatrudnienia i/lub nieformalnej działalności, aby postrzegana ona była nie jako uciążliwy wysiłek, ale jako sposób na doskonalenie samego siebie i świata. Taka praca powinna posiadać sens - jego odczucie rodzi motywację do podjęcia wysiłku działania. Do pracy pobudza świadomość jej celowości, wyrażającej się odległością między tym, co obecnie człowiek posiada, a tym, co chce osiągnąć (Tischner 1985). Praca nie musi być źródłem wynagrodzenia finansowego, aby była uznana za wartość: wystarczy jeśli jest źródłem spełnienia, przydatności i przynależności społecznej.

\section{Teorie motywacji do pracy}

Teorie motywacji można rozpatrywać w ujęciu tradycyjnym i przedmiotowym. W płaszczyźnie przedmiotowej wyróżnia się teorie treści (określane również jako teorie potrzeb), dociekające źródeł ludzkiej motywacji (co motywuje?), czyli wewnętrznych bodźców wywołujących dane zachowanie człowieka. W tym ujęciu potrzeby generują stan niedostatku, który motywuje jednostkę do podjęcia aktywności ukierunkowanej na zaspokojenie jej potrzeb. W dziedzinie pracy zawodowej poznanie potrzeb pracowników i dysponowanie możliwościami ich zaspokajania pozwala przewidzieć motywy postępowania zatrudnionych osób i na nie wpływać. W dużo szerszej perspektywie ludzkie potrzeby i motywacje ujmowane są poprzez teorie procesu, których zadaniem jest wyjaśnienie sposobów aktywizowania, ukierunkowywania, wzmacniania i wygaszania ludzkich działań, związanych z zaspokajaniem własnych potrzeb. Powstają pytania o sposoby motywowania człowieka (jak motywować?). W ujęciu chronologicznym można przyjąć, że wpierw rozwinęły się teorie treści, następnie teorie procesu, obecnie zaś silnie 
podkreśla się i realizuje potrzebę scalania dorobku teoretycznego i empirycznego $\mathrm{w}$ tej dziedzinie w postaci teorii zintegrowanych.

Teorie motywacji sięgają swym początkiem starożytnej filozofii hedonizmu, zakładającej, że ludzie w podejmowanych działaniach szukają przyjemności i unikają cierpienia. Z końcem XIX wieku pojęcie motywacji z kręgu zainteresowań filozoficznych przeniesiono w zakres badań stosunkowo nowej nauki - psychologii. Na początku XX wieku dużą popularność zdobyła teoria motywacji do pracy stworzona przez przemysłowca Fredericka Winslowa Taylora (1911) na gruncie jego zawodowych kierowniczych doświadczeń praktycznych. Jako twórca tzw. modelu tradycji czerpał on z doświadczeń feudalizmu opartego na dominującej roli zarządcy w relacji z podwładnym i szerokim wachlarzu stosowanych wobec niego środków przymusu psychicznego, fizycznego i administracyjnego. Wychodząc z założenia, że praca jest w swej istocie nieprzyjemna, oddzielał funkcje koncepcyjne od wykonawczych, uznając przełożonych za najbardziej kompetentnych w organizowaniu pracy. Wyrażał przekonanie, że pracowników, jako z natury leniwych, trzeba do pracy nakłaniać, zwłaszcza środkami pieniężnymi, zyskując zwiększoną efektywność ich działania w zamian za podwyżkę płacy. Motywacja jest tu motywacją człowieka homo economicus, preferującego korzyści materialne i opierającego swą działalność wyłącznie na podstawie kalkulacji ekonomicznej. Dochód staje się ważniejszy od samej pracy. Z drugiej strony, w efekcie przeprowadzonego eksperymentu twórca modelu tradycji zwrócił uwagę na fakt, że zwiększona efektywność pracy prowadzi do redukcji nadwyżki etatów, co z kolei zwiększa motywację do utrzymania zatrudnienia, górującą nad motywacją do większego zarobku.

W latach 50. XX wieku rozwinęły się tzw. teorie treści, których celem było zidentyfikowanie czynników pobudzających motywację. Najpopularniejszą, najszerzej akceptowaną i cytowaną koncepcją stała się w tym zakresie teoria hierarchii potrzeb (Need Hierarchy Theory) Abrahama Harolda Maslowa (1943). Proponuje on prosty schemat hierarchicznego podziału potrzeb na pięć grup: zaspokajane zewnętrznie potrzeby fizjologiczne (physiological needs) i potrzeby bezpieczeństwa (safety needs) jako potrzeby podstawowe, potrzeby społeczne (social needs-belongingness), potrzeby uznania (esteem needs) i potrzeby samorealizacji (self-actualization) jako spełniane wewnętrznie potrzeby wyższe. Zachowaniem człowieka kierują jego niezaspokojone potrzeby. Ich realizacja następuje w określonej sekwencji. Spełnianie potrzeb niższych warunkuje pojawienie się i zaspokojenie potrzeb znajdujących się wyżej w zaproponowanym układzie. W tym ujęciu motywacja nie przychodzi z zewnątrz, ale wypływa z potrzeb jednostki zaspokajanych w hierarchicznym porządku. Zaspokojona potrzeba niższego rzędu nie wzbudza motywacji. Motywatorami stają się wówczas uaktywnione potrzeby wyższe.

W tej teorii niezaspokojenie potrzeb niższego rzędu narusza równowagę całego organizmu, ich zaspokojenie równowagę tę przywraca, co tłumaczyć ma prawo homeostazy. Wobec potrzeb wyższego rzędu zastosowanie znajduje prawo 
wzmocnienia - ich zaspokajanie odczuwane jest jako przyjemne, co prowadzi do ich wzmocnienia i wzmaga motywację w kierunku ich zaspokajania. Rozwój człowieka pobudzany jest przez nasilającą się motywację w kierunku zaspokajania potrzeb wyższych. Teoria hierarchii potrzeb A.H. Maslowa, powszechnie znana i na trwałe zakorzeniona w nauce, pomimo przekonującej prostoty i spójności nie znalazła rzetelnego poparcia w badaniach empirycznych.

Clayton Alderfer (1969) postrzegał zachowanie człowieka w sposób bardziej złożony, aniżeli uczynił to A.H. Maslow. W swej teorii ERG (ERG Theory) dowodził, że może na nie wpływać jednocześnie kilka czynników motywujących, tj. człowiek może odczuwać kilka potrzeb naraz. Zaprezentował zmodyfikowaną wersję hierarchii potrzeb A.H. Maslowa, wyróżniając trzy podstawowe zazębiające się płaszczyzny: egzystencji (existence), związku, tj. kontaktów społecznych (relatedness) oraz wzrostu lub rozwoju (growth) - ERG. Płaszczyzny te odpowiadaja wymienionym przez A.H. Maslowa potrzebom: fizjologicznym i bezpieczeństwa (E), przynależności i szacunku (R) oraz samorealizacji (G). Zaspokojone potrzeby tracą na swej ważności, wyłączając potrzeby rozwoju, które w miarę zaspokajania się nasilają. C. Alderfer podzielił również potrzeby według czasu ich odczuwania na krótkotrwałe, długotrwałe i okazjonalne. Wyjaśnił pojęcia frustracji i regresji. Jego zdaniem frustracja pojawia się wskutek niemożności zaspokojenia potrzeb wyższego rzędu i skłania do cofnięcia się (regresji) w hierarchii potrzeb do etapu powtórnego, zintensyfikowanego tym razem zaspokajaniem potrzeb niższego rzędu, w wyniku czego ulega redukcji. Demotywacja natomiast oznacza przeniesienie $\mathrm{w}$ wyniku odczuwanego niezadowolenia niespełnionych wobec danej potrzeby pragnień na inną płaszczyznę potrzeb. Zdaniem C. Alderfera zaspokajanie uporządkowanych hierarchicznie potrzeb ludzkich nie jest ani jednokierunkowe, ani liniowe. Człowiek może dążyć do zaspokojenia wielu potrzeb jednocześnie i poruszać się na ich hierarchicznym schemacie do góry, jak i w dól, w zależności od życiowych uwarunkowań. Teoria ta uchodzi za bardziej trafną wersję hierarchii potrzeb i w większym stopniu wsparta jest badaniami naukowymi w kontekście motywacji w pracy zawodowej (Luthans 1998).

Zainspirowany teorią potrzeb A.H. Maslowa, David McClelland (1985) rozwinął teorię trychotomii potrzeb (Trichotomy of Needs), w której, ignorując hierarchię potrzeb, szczegółowej analizie poddał potrzeby wyższego rzędu: przynależności, szacunku, samorealizacji. W odróżnieniu od A.H. Maslowa twierdził, że człowiek może równocześnie odczuwać, choć w różnym natężeniu, wszystkie potrzeby, ale to potrzeba dominująca motywuje do działania. Wychodził z założenia, że potrzeby mogą być nabyte na drodze własnego doświadczenia, a środowisko człowieka może prowadzić do wzmacniania poszczególnych potrzeb, przypisanych do trzech zasadniczych grup: potrzeba władzy (need for power) - manifestująca się potrzebą wywierania wpływu na środowisko i kontrolowania go, potrzeba afiliacji (need for afiliation) - pragnienie obecności innych i ich akceptacji, potrzeba osiągnięć (need for achievement) - pragnienie pełnej i coraz bardziej skutecznej realizacji 
celów. Potrzeba władzy skłania do kontrolowania własnej sytuacji (władza osobista) oraz zachowań innych i wywierania na nie wpływu (władza społeczna). Może przybierać formę pozytywną, pobudzając do zachowań prospołecznych lub negatywną, kształtując postawę egoistyczną. Osoby motywowane potrzebą afiliacji będą najlepiej działać $\mathrm{w}$ atmosferze społecznej akceptacji, przynależności i zintegrowania. Osoby pragnące osiągnięć będą motywowane możliwością wyróżnienia się i odniesienia sukcesu, skupiając się na jak najefektywniejszym wykonywaniu ambitnych zadań. Dalsze badania D. McClelland prowadził wokół potrzeby osiągnięć, uznając ją za najsilniejszy, nabyty w toku doświadczenia motyw do pracy, stąd też rozwinięta przez niego koncepcja zwana jest również teorią osiągnięć. Zgodnie z jej założeniami, w pracy zawodowej obowiązkiem kierownika będzie przydzielanie zadań zgodnie z rozpoznaną u pracownika dominującą potrzebą, co zakłada indywidualizację systemu motywacyjnego organizacji. Z uwagi na najwyższą heterogeniczność populacji osób starszych ze wszystkich kategorii wiekowych, indywidualnie zaprojektowane strategie motywowania będą miały szczególne znaczenie. Prowadzone nad tą teorią badania empiryczne wskazały na jej braki, np. nieuwzględnienie takich wykazujących predyktywną wartość czynników motywujących do pracy, jak radość w wykonywania zadań czy przywiązanie do zasad i wartości (Barbuto i in. 2002).

Teoria dwuczynnikowa (Motivation-Hygiene Theory), autorstwa Fredericka Herzberga i in. (1959), skupia się na źródłach satysfakcji z pracy i sposobach takiego jej zorganizowania, aby była ona wzbogacająca i rozwijająca. W przeciwieństwie do koncepcji A.H. Maslowa, wywodzącej się z teoretycznych rozważań, w późniejszym etapie poddanych weryfikacji empirycznej, swą koncepcję F. Herzberg oparł na wynikach analizy 203 wywiadów przeprowadzonych z inżynierami i księgowymi. Podobnie jak A.H. Maslow zastosował hierarchię potrzeb, które podzielił na dwie grupy: zewnętrzne (czynniki niezadowolenia lub higieny psychicznej), odnoszące się do środowiska pracy, jak: styl zarządzania, formy nadzoru, stosunki międzyludzkie, warunki pracy, wynagrodzenie, świadczenia socjalne oraz czynniki wewnętrzne (zadowolenia lub motywacji), dotyczące treści pracy, jak: zainteresowanie pracą, uznanie, osiągnięcia, odpowiedzialność, awans, osobisty rozwój. Powyższe grupy czynników w sposób niezależny od siebie wpływają na zachowanie człowieka. Deprywacja czynników zewnętrznych prowadzi do dyssatysfakcji i spadku wydajności pracy. Ich zaspokojenie pozwala likwidować niezadowolenie i zapobiegać dyssatysfakcji, jest niezbędne dla zachowania aktualnego poziomu zaangażowania pracownika $\mathrm{w}$ pracę. Zadowolenie i satysfakcję $\mathrm{z}$ pracy mogą wywołać jednak wyłącznie czynniki wewnętrzne, prowadząc do wyższej wydajności pracowników i do ich osobistego rozwoju.

Dużą wartość teorii dwuczynnikowej F. Herzberga upatruje się w odkryciu, że na zadowolenie lub niezadowolenie z pracy wpływają dwie odrębne grupy czynników. Satysfakcję z pracy wywołują czynniki wewnętrzne, tzw. motywatory (motivators), dyssatysfakcja wynika zaś z czynników higieny psychicznej. Satysfakcja 
i dyssatysfakcja nie są zatem przeciwieństwami, choć są wobec siebie komplementarne. Przeciwieństwem satysfakcji będzie brak satysfakcji a nie dyssatysfakcja. Brak satysfakcji nie oznacza dyssatysfakcji. Zadowolenie i niezadowolenie pracownika to zatem zmienne niezależne. Pracownik może odczuwać stan również limbo, czyli brak satysfakcji i zarazem dyssatysfakcji, oznaczający stan nieproduktywności dla pracownika i organizacji.

Teoria Herzberga została poddana empirycznej weryfikacji. Niektóre z założeń teorii dwuczynnikowej nie znalazły empirycznego potwierdzenia, np. założenie, że zadowolenie pracowników z czynników wewnętrznych i zewnętrznych najsilniej motywuje ich do pracy. Okazało się, że wyniki uzyskane przez Herzberga są powtarzalne wyłącznie przy identycznie wedle oryginału zaprojektowanej metodologii (Christopher 2005).

W swojej teorii pracy Douglas McGregor (1960) nakreślił dwa modelowe przeciwstawne przeświadczenia kierowników na temat natury pracowników, wpływające na ich stosunek wobec podwładnych. W teorii „X” przedstawił człowieka leniwego, pozbawionego ambicji, unikającego odpowiedzialności i stroniącego od pracy, którego do podjęcia wysiłku należy zachęcać, zmuszać, karać lub przekupywać i nagradzać. Motywem jego pracy są pieniądze i obawa o bezpieczeństwo. Teoria „Y” prezentuje człowieka zdyscyplinowanego wewnętrznie, twórczego, lubiącego pracę, szukającego okazji do pracy postrzeganej jako koniecznej dla własnego rozwoju i źródło satysfakcji. Powyższe profile ludzkiej natury odzwierciedlają dwa zupełnie różne style motywowania pracowników. Przełożeni wyznający założenia teorii „X” będą stosować motywatory finansowe i ścisły nadzór, natomiast kierownicy przekonani o prawdziwości założeń teorii „Y” będą skłonni obdarzyć podwładnych zaufaniem i swobodą $\mathrm{w}$ wykonywaniu powierzonych zadań, zachęcać ich do działań twórczych i innowacyjnych, pozwalając im na zintegrowanie celów własnych z celami organizacji. Sam D. McGregor preferował teorię „,”, wierząc, że praca stanowi naturalną aktywność człowieka, motywowanego wewnętrznie, samodzielnie narzucającego sobie dyscyplinę i odpowiedzialność, szukającego możliwości wykorzystania i rozwinięcia własnego potencjału. Wskazywał na możliwość kształtowania u podwładnych stosunku do pracy, poprzez stwarzanie warunków do ich dojrzewania w kierunku modelu pracownika realizującego założenia teorii "Y”. Choć McGregor nie publikował wiele, jego teoria pracy i humanistyczna wizja pracownika, obecnie wsparta empirycznym materiałem dowodowym, wywarły silny wpływ na rozwój strategii zarządzania zasobami ludzkimi.

Lata 6o. i 70. XX wieku to okres rozkwitu teorii przyjmujących za cel wyjaśnienie procesu leżącego u podstaw motywacji do pracy. W przeciwieństwie do teorii treści, skupiających się na identyfikacji czynników związanych z motywacją $\mathrm{w}$ relatywnie statycznym środowisku, teorie procesu ujmowały motywację do pracy z dynamicznej perspektywy. Kluczowe znaczenie dla teorii procesu mają teorie poznawcze (cognitive theories), a wśród nich teoria sprawiedliwości (Equity Theory), autorstwa Johna Stacey’a Adamsa (1963), która zwraca uwagę na właściwe 
pracownikom poczucie sprawiedliwości, wyrastające z naturalnej ludzkiej skłonności do porównywania się, które w dziedzinie pracy zawodowej przekłada się na odczuwany poziom motywacji do pracy. U jej podstaw leży założenie, że pracownik oczekuje sprawiedliwych korzyści (outcomes) za poniesione nakłady pracy (input), porównując uzyskany wynik własny z wynikami innych. Subiektywnej oceny stosunku poniesionych nakładów pracy do uzyskanego wynagrodzenia dokonuje w porównaniu do kosztów i zysków będących udziałem osoby przyjętej za punkt odniesienia. Obiektem odniesienia mogą być inni pracownicy organizacji, standardy wewnętrzne organizacji, jak również doświadczenia własne jednostki. Motywacja pracownika pojawia się wskutek odczuwania przez niego zadowolenia $\mathrm{z}$ dokonanego szacunku korzyści otrzymywanych w zamian za włożony w pracę wysiłek. Wykonana ocena sprawiedliwości może wprowadzać stan sprawiedliwości (jeśli ocena własna i osoby przyjętej za punkt odniesienia jest taka sama), stan przewartościowania (jeśli ocena pracownika jest większa od oceny osoby porównywanej), stan niedowartościowania (jeśli wynik oceny własnej jest niższy od oceny porównywanej osoby). Stan sprawiedliwości to zatem stan równowagi między własnymi kosztami i nakładami, jak również zyskiem własnym i innych. Odczuwany stan sprawiedliwości wygasza motywację do wprowadzania jakichkolwiek zmian w zakresie ponoszonych nakładów czy uzyskiwanych korzyści. Wszelkie odchylenia od pożądanego stanu równowagi (przewartościowanie i niedowartościowanie) wywołują napięcia domagające się rozładowania w wymiarze emocjonalnym i behawioralnym. Podjęte zmiany mogą dotyczyć modyfikacji stosunku wynagrodzenia do wkładu (wybór i wartościowanie ponoszonych nakładów i uzyskiwanych korzyści) lub wyboru i oceny przyjmowanego punktu odniesienia.

Stan przewartościowana wywołuje słabsze napięcia i jest przez pracownika łatwiej akceptowany aniżeli stan niedowartościowania. O ile jednak w subiektywnym odczuciu stan przewartościowania może zostać zaakceptowany, o tyle wśród innych pracowników, przyjmujących za obiekt odniesienia pracownika przewartościowanego, może dojść do relokacji poczucia niesprawiedliwości i napięcia. Dla pracowników motywujące będą takie sytuacje, które dają im zadowolenie z nagród uzyskiwanych proporcjonalnie do ponoszonych nakładów. Dotychczasowe badania empiryczne nie podważają prawdziwości przyjętych założeń, ale wskazują na potrzebę dalszej empirycznej eksploracji tematu.

Do innych ważnych poznawczych teorii motywacji do pracy należy teoria oczekiwań (Expectancy Theory), autorstwa Victora Harolda Vrooma (1964), wywodząca się z wczesnych prac Kurta Lewina i Edwarda Chace’a Tolmana, którzy postrzegali zachowania ludzkie jako celowe i w dużej mierze świadome. V.H. Vroom za punkt wyjścia przyjął założenie, że ludzie, zróżnicowani w zakresie wyznawanych wartości i potrzeb, umiejętności, wiedzy i doświadczenia, działają racjonalnie i logicznie. Decydują się na określony sposób zachowania, ważąc prawdopodobieństwo osiągnięcia w ten sposób własnych celów i zaspokojenia indywidualnych potrzeb. 
Wybór zachowania to proces przebiegający w trzech etapach: oczekiwana relacja wysiłku do osiągnięć (oczekiwanie/expectancy), oczekiwana relacja osiągnięć do wyników w postaci nagrody (instrumentalność/instrumentality), oczekiwane zaspokojenie potrzeby dzięki uzyskanej nagrodzie (walencja/valence). Na zachowanie pracownika wpływają zatem czynniki wewnętrzne i zewnętrzne: oczekiwania własne, instrumentalność wyniku oraz cenność nagród. Na każdym z etapów pracownik dokonuje subiektywnej oceny wartości relacji, od czego zależy wzbudzenie motywacji do określonego działania.

O poziomie motywacji, jako skłonności do ponoszenia wysiłku, decyduje siła pragnienia i oczekiwanego prawdopodobieństwa jego zaspokojenia. Dla podjęcia przez pracownika działania zasadnicze znaczenie ma jego przekonanie, że włożony wysiłek wystarczy do wykonania zadania i otrzymania wynagrodzenia. Pozytywnie ocenione szanse zdobycia celu przy pomocy konkretnych zasobów własnych (np. charakter, kompetencje) i środowiskowych (np. dostęp do informacji, relacje ze współpracownikami) dają początek motywacji, która staje się bezpośrednim bodźcem pobudzającym do działania. Oczekiwanie (expectancy) zatem pozwala ocenić, czy zamierzony sposób postępowania może być zakończony pomyślnie. Na kolejnym etapie procesu wzbudzania motywacji dochodzi do dostrzeżenia związku między pozytywną realizacją powierzonych obowiązków a otrzymywanymi nagrodami. Kształtuje się przekonanie pracownika o tym, czy oczekiwana nagroda jest osiągalna. W dalszym etapie pracownik poddaje ocenie związek zachodzący między możliwością zdobycia nagrody a możliwością zaspokojenia dzięki niej własnych potrzeb. Im bardziej nagroda jest pozytywna, tym silniejsza jest motywacja pracownika do osiągnięcia zamierzonego celu. Nagrody mają służyć zaspokajaniu potrzeb, dlatego nadają działaniu wartość. Siła motywacji do podjęcia określonego zachowania zależy zatem od subiektywnej oceny wartości powyższych czynników: oczekiwania, instrumentalności, walencji. Pracownik jest dobrze zmotywowany, kiedy czuje, że jego wysiłki prowadzą go do osiągnięcia takiego poziomu wykonania pracy, który może być pozytywnie nagrodzony.

Teoria oczekiwań jest szeroko akceptowana w nauce oraz, pomimo swej złożoności, w praktyce zarządzania pracownikami. Jej kontynuacji podjęli się L.W. Porter i E.E. Lawler (Porter, Lawler 1968), którzy zaproponowali model wewnętrznej i zewnętrznej motywacji. Zgodnie z nim ludzie wewnętrznie motywowani podejmują daną czynność dlatego, iż uważają ją za interesującą i czerpią z niej przyjemność. W przypadku motywacji zewnętrznej źródłem satysfakcji staje się nie tyle samo wykonywanie czynności, co skutki, do których ona prowadzi.

Teoria wzmocnienia (Reinforcement Theory), zwana także teorią modyfikacji zachowań lub teorią uczenia się, wprowadza pojęcie nauki w zachowaniach motywacyjnych. Choć rozwijana była aż do czasów współczesnych, to Burrhusa Federicka Skinnera (1953) uznaje się za jej głównego twórcę. W swych badaniach, czerpiąc z dorobku psychologii behawioralnej, wyszedł on z założenia, że zachowaniem człowieka, nastawionym na zaspokajanie potrzeb, kieruje instynkt. 
Podkreślał rolę uczenia się w kształtowaniu przyszłych zachowań, na podstawie dokonywanej oceny związku między podjętymi w przeszłości działaniami a ich skutkami. W drodze uczenia się indywidualna aktywność jednostki jest skutkiem jej nabytych doświadczeń w zakresie nagród i kar otrzymywanych za określone działania. Decyzje dotyczące teraźniejszości podejmowane są na podstawie nagród i kar otrzymanych za minione zachowania. Prawo skutku mówi o tym, że człowiek wykazuje skłonność do powtarzania zachowań, które w przeszłości przyniosły przyjemne konsekwencje, były nagradzane oraz unikania tych, które były nieprzyjemne bądź karane. Dochodzi do modyfikacji zachowania zgodnie z wzorcem: bodziec-reakcja-skutki-przyszłe reakcje.

Zachowanie człowieka jako istoty reaktywnej determinowane jest zatem przez czynniki środowiskowe i związane z nimi własne doświadczenia dlatego, aby kierować jego działaniem, należy wpływać na jego otoczenie. Człowiek przyswaja pewne zachowania, zyskujące $\mathrm{z}$ czasem charakter nawykowy. Pracodawca może zatem operować czterema rodzajami modyfikacji zachowań: wzmocnieniami pozytywnymi (nagrody, pochwały), wzmocnieniami negatywnymi (mającymi na celu korektę zachowań i przeorientowanie na pożądane działania), eliminacją (brak wzmocnienia celem zignorowania i w następstwie wyeliminowania niepożądanych zachowań pracownika) i karami (nieprzyjemne skutki za zaistniałe negatywne zachowanie). Niewzmocnione zachowania pozytywne mogą zaniknąć.

Teoria uczenia się społecznego (Social Learning Theory), autorstwa Alberta Bandury (1977), inspirowana przez prace Neala Millera oraz Johna Dollarda, łączy założenia teorii wzmocnienia B.F. Skinnera oraz teorii ustalania celów Edwina Locke’a. To koncepcja bardzo szeroka, dalece wykraczająca poza tematykę motywacji do pracy. Jednak kluczowe dla niej pojęcie poczucia własnej skuteczności, sprawstwa (self-eficacy), okazało się wywierać silny motywacyjny wpływ za ludzkie zachowanie. W swym podstawowym wymiarze teoria ta zakłada wzajemne oddziaływanie czynników środowiskowych i umysłowych. Przekonuje, że zachowanie człowieka jest efektem jego procesu myślowego opartego na analizie własnych doświadczeń oraz obserwowanych zjawisk zachodzących w otoczeniu, szczególnie zaś zachowań innych, postrzeganych jako modelowe. W wyniku dokonanej analizy człowiek może podjąć decyzję o zaprzestaniu dotychczasowych zachowań, odrzucić zachowania innych lub też wykreować zupełnie nowatorskie rozwiązania. Choć w procesie modelowania człowiek jest kształtowany przez swoje środowisko, w swych działaniach nie pozostaje bezwolną sterowaną zewnętrznie istotą, ponieważ również sam, przetwarzając dane zewnętrzne, stanowi o swoim zachowaniu oraz wpływa na środowisko zewnętrzne, np. będąc modelem zachowania dla innych.

Proces uczenia się zachowania przebiega w czterech etapach: obserwacji (attention) zachowaniach i wyborze modelu, zapamiętaniu (retention) zachowaniu modelu i wynikających z niego skutków, zachowaniu (reproduction) zapamiętanych modelowych informacji w postaci własnego modelu zachowań, wzmocnieniu 
(reinforcement), jako reakcji otoczenia na wypracowane zachowanie jednostki, które może to zachowanie wzmocnić bądź osłabić.

Ludzka motywacja i działanie są regulowane przez umysłową kontrolę zachowania, bazującą na trzech rodzajach przekonań: 1) ogólne oczekiwanie wyniku osiągalnego bez względu na jednostkowe działania; 2) oczekiwanie konkretnego wyniku uzależnionego od osobistych działań; 3) skuteczność własna (self-efficacy) przekonanie o zdolnościach jednostki do osiągnięcia określonego wyniku. Pewność siebie (self-confidence) leży u podstaw motywacji człowieka do działania. Na gotowość jednostki do podjęcia zadań silny wpływ wywiera jej subiektywne przekonanie o własnej skuteczności, czyli wiara we własne siły i możliwości (Bandura 1982). Im jest ona silniejsza, tym większe jest prawdopodobieństwo wzbudzenia aktywności i jej podtrzymania.

Na gruncie pracy zawodowej teoria ta proponuje modelowanie zachowań pracowników przez dostarczanie ich wzorca. Prawdopodobieństwo przyjęcia modelu jest tym większe, im będzie on pod pewnymi względami bardziej przystosowany do danego pracownika, im wzorzec zachowań będzie dla kogoś znaczący, czy też jeśli pracownik będzie podlegał bezpośredniej obserwacji i ocenie. Modelowanie powinno uwzględniać indywidualne różnice między pracownikami. Prognozę zachowań podwładnych umożliwia znajomość subiektywnej oceny posiadanych przez nich umiejętności i zdolności, a ich modyfikację np. proponowany system doskonalenia zawodowego.

Choć Bandura budował swoją teorię na podstawie obserwacji studentów i badaniu ich zachowań, uzyskane przez niego wyniki znajdują zastosowanie w dziedzinie motywowania pracowników. Metaanaliza, przeprowadzona przez Sadri i Robertson (1993), jak również badania autorstwa Stajkovic i Luthans (2003) dobitnie wykazały, że poczucie skuteczności motywuje pracowników do pracy i wpływa na sposób jej wykonania.

\section{Motywacja zawodowa osób starszych}

Wiek średni to okres najwyższej satysfakcji z pracy zawodowej i często najwyższych osiągnięć. Z czasem jednak dochodzi do zmian w sferze funkcjonowania fizycznego, psychicznego i społecznego pracownika, jak również w stosunku otoczenia społecznego wobec starzejącej się osoby, rzutującego na jej motywację do pracy i chęć kontynuowania zatrudnienia. Badania zagraniczne podają, że ok. 60 proc. podwładnych przed wycofaniem się z pracy zawodowej wybiera zatrudnienie na część etatu (Cahill i in. 2006), ok. 15 proc. emerytowanych pracowników ponownie wchodzi na rynek pracy (Cahill i in. 2011). Widoczna jest zatem tendencja do stopniowego wycofywania się z aktywności zawodowej przed całkowitym przejściem na emeryturę.

Wielu seniorów pragnęłoby kontynuować pracę zawodową pomimo osiągnięcia wieku emerytalnego - badania ogólnoświatowe (Kałuża, Lewandowska-Szweda 
2006), ujawniły, że tylko 20 proc. pracowników planuje trwałą dezaktywację zawodową, natomiast 75 proc. $z$ nich chciałoby nadal pracować, najchętniej w niepełnym wymiarze czasu (7o proc.), rzadziej na cały etat (7 proc.). Do kontynuowania pracy zawodowej najsilniejszą zachętę stanowią: kwestie finansowe (25 proc.), potrzeba wartościowego spędzania czasu (22 proc.), chęć zachowania dobrej kondycji fizycznej (21 proc.), kontakt $z$ innymi ludźmi i okazja do stymulacji umysłowej (13 proc.). Dla polskich seniorów najistotniejszym powodem, dla którego chcieliby kontynuować pracę zawodową, jest przede wszystkim chęć kontaktu z innymi ludźmi (33 proc.). Motywy finansowe wymieniane są dopiero na drugim miejscu (21 proc.), niemal na równi z pragnieniem wartościowego spędzania czasu (20 proc.).

O kontynuowaniu bądź zakończeniu pracy zawodowej w wysokim stopniu decyduje stan zdrowia oraz zdrowie najbliższych. Wielu zaawansowanych wiekowo pracowników przechodzi na emeryturę niedobrowolnie, tj. z powodu niepełnosprawności własnej czy konieczności sprawowania opieki nad chorymi rodzicami czy współmałżonkiem. Za pośrednią przyczynę odejścia z pracy z powodów zdrowotnych uznaje się osłabioną w tej sytuacji motywację do pracy, co można uznać za oddanie pierwszeństwa potrzebom fizycznym nad realizacją zawodową. Podobnie pragnienie kontynuowania pracy zawodowej uzależnione jest od sytuacji rodzinnej, np. wspomniana konieczność pełnienia roli opiekuna wobec chorego lub niepełnosprawnego współmałżonka lub rodziców, jak również dowiedziona tendencja do synchronizowania czasu przechodzenia na emeryturę przez małżeństwa (Szinovacz i in. 2001).

Badania wskazują na wysoką motywację do pracy wśród starszych pracowników, jednak ich motywy zmieniają się w ciągu życia. Podwładnych do pracy motywuje co innego niż pracowników w starszym wieku. Dla młodszych pracowników większe znaczenie mają dochód i możliwość awansu (Warr 1992), dla starszych - gwarancja stałego zatrudnienia oraz bezpieczeństwo fizyczne (Warr 1997). Pracowników $\mathrm{W}$ wieku 50+ do pozostania na rynku pracy skłania radość z wykonywanej pracy, satysfakcja $\mathrm{z}$ wykorzystywania własnych umiejętności i kreatywności, poczucie zawodowych osiągnięć (Lord 2004). Jak pokazują wyniki badań (Frasera i in. 2009), do kontynuowania pracy zachęcają: kwestie finansowe, pragnienie wnoszenia własnego wkładu, brak rywalizacji, zachowanie zdrowego stylu życia, posiadanie pasji do pracy i edukacja. Do przeszkód w kontynuowaniu pracy zawodowej należą zaś: stres, brak wsparcia, wymagania fizyczne i przesadny nacisk na kwalifikacje. Do dezaktywacji zawodowej skłania ponadto niepewność zatrudnienia, chroniczne zmęczenie pracą, brak satysfakcji z wykonywanej pracy, zła atmosfera wywołana m.in. presją na zwolnienie miejsca pracy osobom młodszym. Dla polskich seniorów najważniejszym powodem przechodzenia na emeryturę jest stan zdrowia i kondycja fizyczna (dla 51 proc. kobiet i 53 proc. mężczyzn) (MPiPS 2008). Kemp (1988) i Resnick (1991) sugerują istnienie zmian w motywacji między starszymi i młodymi ludźmi, uwarunkowane przesunięciem od motywacji osiągnięć (achievement motivation) do motywacji zachowania (conservation motivation). 
U pracowników w starszym wieku satysfakcja z pracy jest bliżej związana z wewnętrznymi czynnikami niż zewnętrznymi nagrodami w porównaniu z młodszymi pracownikami (Valentine i in. 1998). Należą do nich np. wykonywanie zadań mających znaczenie, wartości etyczne w pracy, niezależność, współpraca z innymi, percepcja własnego wykonania, samodzielne wykonywanie zadań. Zmniejsza się za to znaczenie osiągnięć, kariery i szkoleń (Kooij 2010). Zdaniem zaawansowanych wiekowo pracowników do kontynuowania przez nich pracy zawodowej skłania zdrowy styl życia oraz pasja do pracy i uczenia się (Frasera 2009). Inne badania, autorstwa R.L. Lorda i P. Farringtona (2006), potwierdzają wysoką motywację do pracy wśród seniorów, nawet wyższą niż u młodszych podwładnych. Stwierdzono znaczącą w tych grupach wiekowych różnicę w ocenie różnych czynników związanych z pracą. Starsze osoby były bardziej zadowolone od młodszych w zakresie: poczucia osiągnięć, dobrych stosunków ze współpracownikami, możliwości wypróbowania nowych metod, wyrażania własnych poglądów, wykorzystywania własnych zdolności i wykonywania różnorodnych zadań. Osoby starsze szczególnie potrzebują czuć, że ich praca i wysiłki mają znaczenie i są w organizacji potrzebni. Badania prowadzone wśród starszych pracowników kibucu potwierdzają ich preferencję wobec pracy zaspokajającej wyższe potrzeby nad pracę oferującą lepsze warunki fizyczne czy wygodę (Leviatan 1992).

Wykorzystanie zawodowego potencjału osób w zaawansowanym wieku utrudnia nie tyle brak wiedzy na temat specyfiki ich funkcjonowania, podyktowanej doświadczanymi zmianami rozwojowymi, co stereotypowe, zatem nieprawdziwe i szkodliwe przekonania na ich temat, które z wymiaru mentalnego mogą zostać przeniesione na poziom behawioralny w postaci zachowań dyskryminacyjnych. Przykładem dyskryminacji pracowników z uwagi na ich wiek, $\mathrm{z}$ pominięciem faktycznych umiejętności i efektywności pracy, jest wykluczanie ich na etapie rekrutacji, pominięcie ich w programach szkoleń, czy też ustalanie przymusowego wieku emerytalnego. W efekcie osoby starsze mogą być mniej zmotywowane do pracy i czerpać mniejszą z niej satysfakcję. Jak dowodzą badania (Orpen 1995), doświadczanie ageizmu w miejscu pracy może osłabiać efektywność podejmowanych działań, jak również satysfakcję z wykonywanej pracy, zmniejszać zaangażowanie i przywiązania do miejsca zatrudnienia.

W skrajnych przypadkach dochodzi do internalizacji wiekowych stereotypów, które zaczynają działać jak samospełniająca się przepowiednia. Pracownik-senior, który uwierzył w swą rzekomą niekompetencję i obniżoną zdolność do pracy, będzie bardziej skłonny do jej opuszczenia i wejścia w rolę emeryta. Badania (Gaillard, Desmette 2010) pokazują, że podwładni zapoznani z negatywnym stereotypem wykazywali mniejszą skłonność do rozwoju i uczenia się, za to chętniej rozważali przejście na emeryturę w porównaniu z tymi, którym przedstawiono pozytywny stereotyp pracownika w starszym wieku. Jego niska motywacja może wynikać nie tyle z zaawansowanego wieku, co ze stereotypowego nastawienia i dyskryminującego traktowania w środowisku pracy. 


\section{Podsumowanie i wnioski}

Teorie motywacji do pracy zawodowej, jak również badania empiryczne, prowadzone nad obecnymi i byłymi pracownikami w starszym wieku, wskazują na ich specyficzną motywację do aktywności zawodowej. Okazuje się, że w wieku senioralnym dla działalności zawodowej podstawowe znaczenie ma stan zdrowia, co oddaje słuszność klasycznej teorii potrzeb Maslowa. Co jednak charakterystyczne, kwestie finansowe, tak silnie związane z zabezpieczeniem własnego bytu, choć ważne, nie są dla seniorów najistotniejsze. Na czoło wysuwa się potrzeba wartościowego spędzania czasu, kontakt z innymi ludźmi, a także uczenie się i aktywność umysłowa.

W młodszym wieku silnym stymulatorem jest dochód i możliwość awansu, w starszym: radość z wykonywanej pracy, satysfakcja z wykorzystywania własnych umiejętności i kreatywności, poczucie zawodowych osiągnięć, wykonywanie różnorodnych zadań, mających dla pracownika znaczenie, wartości etyczne w pracy, niezależność, współpraca $\mathrm{z}$ innymi. Praca, która jest pasją, praca, która ma znaczenie - oto powody, dla których seniorzy chcą pracować i czynią to z przyjemnością oraz dobrym skutkiem. Do pracy zniechęcają ich natomiast: stres, brak wsparcia, nadmierny nacisk na kwalifikacje, ageizm. Satysfakcję z pracy odbiera niepewność zatrudnienia, chroniczne zmęczenie pracą, zła atmosfera. W zaawansowanym wieku źródłem satysfakcji z pracy w większej mierze stają się zatem czynniki wewnętrzne aniżeli zewnętrzne nagrody, o czym mówi teoria dwuczynnikowa. Wyniki potwierdzają słuszność założeń teorii ERG, wyodrębniającej tak istotny w starszym wieku czynnik, jak egzystencjalna, społeczna i rozwojowa motywacja do działania. Podobnie teoria trychotomii potrzeb, podkreślająca w procesie wzbudzania motywacji potrzeby wyższego rzędu, czyli: przynależności, szacunku, afiliacji, samorealizacji i osiągnięć, trafnie oddaje specyfikę motywacji do pracy charakterystyczną dla starszych osób.

Po nabyciu uprawnień emerytalnych wielu seniorów nie musi już pracować, ale może i często chce to czynić. Profil takiego pracownika bardziej wpisuje się w teorię „Y” pracy D. McGregora, mówiącą o pracowniku lubiącym swoją pracę, która stanowi dla niego źródło samorozwoju i satysfakcji. Odczuwane korzyści z wykonywanej pracy powinny przeważać nad włożonym wysiłkiem w procesie szacowania jej opłacalności (teoria sprawiedliwości). Wymagana jest taka organizacja pracy, aby pracownik miał możliwość wznieść się na nagradzany poziom wykonania pracy (teoria oczekiwań).

Dla wzbudzenia wśród pracowników w wieku późnej dorosłości motywacji do pracy warto dać im możliwość wykonywania zadań mających dla nich znaczenie, prowadzących do rozwoju i samorealizacji. Dobrze, aby zadania te były wykonywane w kontakcie $\mathrm{z}$ innymi ludźmi, w przyjemnej, pozbawionej stresu i presji atmosferze. Warto nagradzać zachowania pożądane, pamiętając, że zachowania niewzmacniane zanikają. W starszym wieku na wzmacnianie, w toku społecznego 
uczenia się, zasługuje zwłaszcza przekonanie o własnej skuteczności i własnych możliwościach, pobudzające do aktywności, również na polu zawodowym.

Istnieje potrzeba stworzenia strategii mających na celu podniesienie udziału osób starszych w rynku pracy poprzez zachęcanie ich do kontynuowania aktywności zawodowej, w miejsce stosowania środków przymusu. Na przykład przesuwanie wieku uprawniającego do przejścia na emeryturę stanowi próbę wzbudzania motywacji za pomocą zewnętrznych nagród, jaką jest obietnica wyższych świadczeń emerytalnych. Dotychczasowy dorobek naukowy dowodzi jednak, że jest to sposób mniej skuteczny aniżeli pobudzanie motywacji wewnętrznej, bardziej efektywnej dla samego pracownika i pracodawcy.

\section{Bibliografia}

Adams J.S. (1963). Towards an understanding of inequity. "Journal of Abnormal and Social Psychology", 67(5), s. 422-436.

Alderfer C. (1969). An empirical test of a new theory of human needs. „Organizational Behavior and Hurnan Performance", 4(2), s. 142-175.

Bandura A. (1977). Social learning theory. Englewood Cliffs: Prentice-Hall.

Bandura A. (1982). Self-efficacy mechanism in human agency. „American Psychologist", 37(2), s. 122-147.

Barbuto J.E., Fritz S.M., Marx D. (2002). A field examination of two measures of work motivation as predictors of leaders' influence tactics. „Journal of Social Psychology", 142(5), s. 601-616.

Błędowski P. (2013). Aktywność zawodowa osób w starszym wieku. W: Kiełkowska M. (red.). Rynek prac wobec zmian demograficznych. „Zeszyty Demograficzne”. Warszawa: Instytut Obywatelski, s. 53-56.

Cahill K.E., Giandrea D.M., Quinn J.F. (2006). Retirement patterns from career employment. „The Gerontologist”, 46(4), s. 514-523.

Cahill K.E., Giandrea M.D., Quinn J.F. (2011). Reentering the labor force after retirement. „Monthly Labor Review”, 134(2), s. 34-42.

Christopher M. (2005). Meaningful motivation for work motivation theory. „Journal of Management Review", 30(2), s. 235-238.

European Comission, Active Ageing, dostępny na: https://ec.europa.eu/social/ main.jsp?catId=1062\&langId=en (otwarty: 3.06.2020).

Frasera L., McKennab K., Turpinb M., Allenc S., Liddle J. (2009). Older workers: An exploration of the benefits, barriers and adaptations for older people in the workforce. „Work”, 33(3), s. 261-272.

Gaillard M., Desmette D. (2010). (In)validating stereotypes about older workers influences their intentions to retire early and to learn and develop. „Basic and Applied Social Psychology", 32(1), s. 86-98. 
Herzberg F., Mausner B., Snyderman B. (1959). The Motivation to Work, New York: Wiley, dostępny na: https://www.csioz.gov.pl/fileadmin/user_upload/Wytyczne/ statystyka/icf_polish_version_56a8f7984213a.pdf (otwarty: 3.06.2020).

Jan Paweł II (1995). Laborem exercens. Wrocław: WWKA.

Kałuża D., Lewandowska-Szweda Z. (2006), Bariery aktywizacji zawodowej. W: The future of retirement. What people want, London: HSCB.

Kemp B. (1988). Motivation, rehabilitation, and aging: A conceptual model. „Topics in Geriatric Rehabilitation", 3(3), s. 41-51.

Kooij D., Jansen P.G.W., Dikkers J.S.E., De Lange A.H. (2010). The influence of age on the associations between HR practices and both affective commitment and job satisfaction: A meta-analysis. "Journal of Organizational Behavior”, 31(8), s. 1111-1136.

Lawter L., Kopelman R.E., Prottas D.J. (2016). McGregor's Theory X/Y and Job Performance: A Multilevel, Multi-source Analysis, „Journal of Managerial Issues”, 27(1-4), s. 84-101.

Leviatan U. (1992). Determinants of work motivation and work satisfaction among kibbutz aged workers. „Canadian Journal of Community Mental Health”, 11(2), s. $49-64$.

Lord R.L., P. Farrington (2006). Age-related differences in the motivation of knowledge workers. „Engineering Management Journal”, 18(3), s. 20-26.

Luthans F. (1998). Organizational Behavior. Singapore: McGraw-Hill.

Maslow A.H. (1943). A theory of human motivation. „Psychological Review”, 50(4), s. $370-396$.

McClelland D.C. (1985). Human motivation. Glenview: Scott, Foresman.

McGregor D. (1960). The human side of enterprise. New York: McGrawHill.

Pikuła N.G. (2017). Znaczenie pracy zawodowej dla osób po 6o. roku życia. „Studia Edukacyjne", 44, s. 301-315.

Porter L.W., Lawler E.E. III. (1968). Managerial attitudes and performance. Homewood: Irwin-Dorsey.

Resnick B. (1991). Geriatric motivation. Clinically helping the elderly to comply. "Journal of Gerontological Nursing”, 17(5), s. 17-20.

Sadri G., Robertson I.T. (1993). Self-efficacy and work-related behavior: A review and metaanalysis. „Applied Psychology: An International Review”, 42(2), s. 139-152.

Skinner B.F. (1953). Science and human behavior. New York: Macmillan.

Stajkovic A.D., Luthans F. (2003). Social cognitive theory and self-efficacy: Implications for motivation theory and practice. W: Porter L.W., Bigley G.A., Steers R.M. (red.), Motivation and work behawior, Burr Ridge, IL: Irwin/McGraw-Hill, s. 126-140.

Szatur-Jaworska B. (2008). Uczestnictwo osób starszych w sferze publicznej. W: SzaturJaworska B. (red.). Stan przestrzegania praw osób starszych w Polsce. Analiza i rekomendacje działań. Warszawa: Biuro Rzecznika Praw Obywatelskich, s. 115-122. 
Szinovacz M., DeViney S., Davey A. (2001). Influences of family obligations and relationships on retirement: variations by gender, race, and marital status. „Journal of Gerontokgy: Social Sciences", 56(1), s. 20-27.

Taylor F.W. (1911). The principles of scientific management. New York: Harper.

Tischner J. (1985). Polska jest Ojczyzną. Paryż: Editions du Dialogue.

Ustawa o osobach starszych z dnia 11 września 2015 r., Dz. U. 2015 poz. 1705.

Valentine S., Valentine W.R., Dick J. (1998). Intrinsic and extrinsic motivators and older employees' attitudes towards their current jobs. „Perceptual and Motor Skills", 87(2), s. 407-410.

Vroom V.H. (1964). Workand Motivation. New York: John Wiley and Sons.

Warr P.B. (1992). Age and occupational well-being. „Psychology and Aging”, 7(1), S. $37-45$.

Warr P.B. (1997). Age, work and mental health. W: Schaie K.W., Schooler C. (red). The impact of work on older adults. New York: Springer, s. 252-296.

Wiatrowski Z. (2005). Podstawy pedagogiki pracy. Bydgoszcz: Wydawnictwo Akademii Bydgoskiej im. Kazimierza Wielkiego.

World Health Organization (2001). The International Classification of Functioning, Disability and Health (ICF), Geneva: WHO.

\title{
WHAT MOTIVATES SENIORS TO BE SOCIALLY ACTIVE - SELECTED THEORIES OF MOTIVATION
}

\begin{abstract}
The purpose of this article was to determine the motivation of older people to work effectively and undertake professional activity after obtaining retirement rights, in the light of the analysis of classic motivation theories and empirical research. This article review shows that in older age the need for quality time, contact with other people, learning and mental activity, the joy of doing essential tasks, satisfaction with using one's own skills and creativity, and a sense of professional achievement are of fundamental importance. In older age, internal factors rather than external rewards become a source of job satisfaction. To encourage motivation to work among senior citizens, they should be given the opportunity to perform tasks in contact with other people in a pleasant, stress-free and pressure-free atmosphere that leads to development and self-fulfillment.
\end{abstract}

Keywords: motivation; theories of motivation; work; activation; aging. 